\title{
Implementasi Pemilihan Siswa Berprestasi Menggunakan Metode Preferences Selection Index
}

\section{Rahadatul Aisyi*}

Prodi Matematika, Fakultas Matematika dan Ilmu Pengetahuan Alam, Universitas Islam Bandung, Indonesia.

*rahadatu1255@gmail.com

Abstract. Multiple Criteria Decision Making (MCDM) is an operational approach for selecting the best alternative by involving several criteria among many potential alternatives. One of MCDM problem is the selection of exemplary students which must be done properly and objectively. One of the methods to use is the preferences selection index (PSI). The PSI concept does not require weight importance of the criteria, which makes PSI is well constructed in its algorithm. The results showed the recommendation for 5 best alternatives for exemplary students at SMPN X with the highest preference scores $0.98949,0.97755,0.97659,0.975165$, and 0.97229 .

Keywords: Multiple Criteria Decision Making, PSI, Exemplary Student.

Abstrak. Multiple Criteria Decision Making (MCDM) adalah pendekatan operasi yang dapat digunakan dalam proses pengambilan keputusan pemilihan alternatif terbaik dengan melibatkan beberapa kriteria di antara sejumlah alternatif yang berpotensi. Salah satu masalah MCDM adalah dalam pemilihan siswa berprestasi yang harus dilakukan dengan tepat serta objektif. Hal tersebut agar siswa yang terpilih sesuai dengan proporsi kemampuan yang dimiliki sehingga dapat memberikan kontribusi dan tercapainya tujuan yang optimal. Salah satu metode yang digunakan ialah preferences selection index (PSI). Konsep PSI tidak membedakan bobot kepentingan kriteria sehingga PSI terkontruksi dengan baik dalam algoritmanya. Hasil penelitian menunjukkan bahwa perolehan alternatif terbaik siswa berprestasi SMPN X direkomendasikan sebanyak lima orang siswa dengan nilai preferensi tertinggi $0.98949,0.97755,0.97659,0.975165$, dan 0.97229 .

Kata Kunci: Multiple Criteria Decision Making, PSI, Siswa Berprestasi. 


\section{A. Pendahuluan}

Prosedur pengambilan keputusan siswa berprestasi harus dilakukan dengan tepat, yakni diperlukan banyak pertimbangan pendukung khususnya kriteria penilaian agar penghargaan siswa berprestasi lebih proporsional. SMPN X merupakan sekolah yang sering mewakilkan siswa berprestasi untuk diikutsertakan pada kegiatan penalaran keagamaan. Namun, pelaksanaan pemilihan siswa berprestasi sering menimbulkan masalah ketika pihak sekolah kesulitan memilih siswa tersebut menjadi pilihan terbaik. Akhirnya, pihak sekolah mengikutsertakan siswa yang juara kelas tanpa memperhatikan kemampuan pengetahuan agamanya.

Metode pengambilan keputusan harus digunakan secara tepat dengan memanfaatkan data rekap penilaian untuk pemilihan siswa berprestasi. Metode preferences selection index (PSI) ialah metode pendekatan untuk pengambilan keputusan [1]. Metode PSI digunakan untuk memecahkan masalah rasional banyak kriteria dalam pengambilan keputusan Multiple Criteria Decision Making (MCDM). Konsep dasar metode PSI yang digunakan tidak memerlukan bobot atribut, melainkan bobot didapat berdasarkan metodologi objektif menggunakan konsep dasar statistik. Namun, jika kita menginginkan pemberian bobot di luar metodologi, maka dapat diperhitungkan pada data sebelum diolah sebagai suatu matriks keputusan. Dalam metode ini juga tidak diharuskan adanya kepentingan antara atribut dan berguna ketika terdapat konflik dalam memutuskan kepentingan antara atribut.

Pengambilan keputusan menggunakan metode PSI banyak digunakan untuk sarana pemilihan kandidat terbaik, misalnya Siahaan telah menerapkan metode PSI untuk menentukan prioritas pembangunan daerah [2]. Panggabean telah menerapkan metode PSI untuk permasalahan Pengangkatan Supervisor Housekeeping yang menunjukkan perolehan rekomendasi calon Supervisor [3].

Pada penelitian ini, pengambilan keputusan siswa berprestasi menggunakan metode PSI dengan kriteria penilaian berupa jumlah tugas, jumlah hadir, nilai tugas, nilai ujian harian, dan nilai akhir semester dengan mata pelajaran Agama Islam semester II tahun pelajaran 2020/2021. Siswa kelas VII menjadi alternatif yg diseleksi. Penggunaan penentu keputusan menggunakan metode PSI dikarenakan metode yang dipakai merupakan metode baru yang belum sepenuhnya diketahui masyarakat dan metode ini dapat memecahkan masalah dengan baik dari penggunaan algoritma sistematisnya.

\section{B. Metodologi Penelitian}

\section{Data dan Pengambilan Data}

Pada penelitian ini, data diperoleh dengan studi pustaka yaitu mencari informasi dengan mempelajari informasi terkait untuk mendukung pelaksanaan penelitian tugas akhir ini. Data yang digunakan merupakan data rekap penilaian rapor semester II SMPN X dengan kriteria penilaian yaitu jumlah tugas, jumlah hadir, nilai tugas, nilai ujian harian, dan nilai akhir semester di mata pelajaran Agama Islam. Adapun sumber bacaan kepustakaan berasal dari buku-buku teks maupun jurnal ilmiah terkait pengambilan keputusan, metode PSI, dan topik lainnya.

\section{Metode Preference Selection Index (PSI)}

Simulasi pemilihan keputusan menggunakan metode PSI. Adapun penjelasan terkait metode sebagai berikut: Metode PSI berdasarkan Maniya dan Bhat (2010) merupakan salah satu metode untuk memecahkan banyak kriteria pengambilan keputusan. Metode PSI yang digunakan tidak memerlukan bobot atribut, melainkan bobot didapat berdasarkan metodologi objektif menggunakan konsep dasar statistik, juga tidak diharuskan adanya kepentingan antara atribut dan berguna ketika terdapat konflik dalam memutuskan kepentingan antara atribut [4]. Adapun mekanisme penyelesaian PSI dinyatakan [5]-[9], sebagai berikut:

1. Menentukan atribut dan alternatif

Dengan menentukan tujuan serta mengidentifikasi atribut juga alternatif mengenai topik masalah yang akan diambil suatu keputusan.

2. Merumuskan matriks keputusan 
Pada langkah ini, terdapat konstruksi matriks yang diperoleh berdasarkan gambaran atribut. Setiap barisan matriks keputusan dialokasikan ke satu alternatif dan setiap kolom ke satu atribut. Matriks tersebut mempunyai $m$ jumlah alternatif dan $n$ jumlah atribut. Jadi, matriks keputusan ialah matriks berukuran $m \times n$ yang dapat direpresentasikan sebagai berikut:

$$
x_{i j}=\left[\begin{array}{cccc}
x_{11} & x_{12} & \ldots & x_{1 n} \\
x_{21} & x_{22} & \ldots & x_{2 n} \\
\vdots & \vdots & & \vdots \\
x_{m 1} & x_{m 2} & \ldots & x_{m n}
\end{array}\right]
$$

3. Normalisasi matriks keputusan

Jika atribut tersebut adalah tipe menguntungkan, nilai yang maksimum yang diinginkan sebagai akibatnya dapat direpresentasikan sebagai berikut:

$$
N_{i j}=\frac{x_{i j}}{x_{j \max }}
$$

Jika atribut tersebut merupakan tipe tidak menguntungkan, nilai yang minimum yang diinginkan sehingga dapat direpresentasikan sebagai berikut:

$$
N_{i j}=\frac{x_{j \min }}{x_{i j}}
$$

Dengan $x_{i j}$ merupakan ukuran atribut $(i=1,2, \ldots, m$ dan $j=1,2, \ldots, n)$

4. Menghitung nilai rata-rata dari data yang telah dinormalisasi

Pada langkah ini, nilai dari data normalisasi untuk setiap atribut dihitung menggunakan persamaan sebagai berikut:

$$
N_{j}=\frac{1}{m} \sum_{i=1}^{m} N_{i j}
$$

5. Menghitung nilai variasi preferensi

Pada langkah ini, nilai preferensi antara nilai setiap atribut dihitung menggunakan persamaan sebagai berikut:

$$
\sigma_{j}=\sum_{i=1}^{m}\left[N_{i j}-N_{j}\right]^{2}
$$

6. Menentukan penyimpangan di dalam nilai preferensi

$$
\varphi_{j}=1-\sigma_{j}
$$

7. Menentukan bobot untuk setiap kriterianya

$$
\omega_{j}=\frac{\varphi_{j}}{\sum_{j=1}^{n} \varphi_{j}}
$$

8. Menghitung PSI $\left(\theta_{i}\right)$

Dengan menghitung preferensi index $\left(\theta_{i}\right)$ untuk setiap alternatif memakai persamaan sebagai berikut:

$$
\theta_{i}=\sum_{j=1}^{n} N_{i j} \omega_{j}
$$

9. Menentukan pilihan alternatif yang sesuai untuk implementasi yang diberikan.

10. Selanjutnya, masing-masing alternatif dikelompokkan menurut descending untuk memudahkan interpretasi hasil. Alternatif dengan nilai preferensi tinggi akan dikelompokkan terlebih dulu serta begitu seterusnya.

\section{Hasil Penelitian dan Pembahasan}

Selanjutnya akan diimplementasikan metode PSI untuk menyeleksi siswa berprestasi di SMPN $\mathrm{X}$. Terdapat 5 kriteria yang akan digunakan, yaitu jumlah tugas, jumlah hadir, nilai tugas, nilai ujian harian, dan nilai akhir semester di mata pelajaran Agama Islam. Alternatif yang akan diseleksi adalah siswa kelas VII sebanyak 261 alternatif.

\section{Implementasi Metode Preferences Selection Index (PSI)}

Pada pemilihan siswa berprestasi menggunakan metode Preferences Selection Index (PSI) diperlukan adanya kriteria atau atribut untuk dilanjutkan pada proses perhitungannya. Data yang diperoleh akan direpresentasikan ke dalam sebuah matriks keputusan yang menggambarkan alternatif dan atribut. Setiap barisan matriks keputusan dialokasikan setiap baris ke satu alternatif dan setiap kolom ke satu atribut. Matriks tersebut mempunyai $m$ jumlah 
alternatif dan $n$ jumlah atribut. Adapun mekanisme penyelesaian analitik algoritma PSI ditunjukkan melalui tabel dibawah ini:

1. Matriks Keputusan

Tabel 1. Matriks Keputusan

\begin{tabular}{|c|c|c|c|c|c|}
\hline & $n_{1}$ & $n_{2}$ & $n_{3}$ & $n_{4}$ & $n_{5}$ \\
\hline$m_{1}$ & 14 & 20 & 80 & 85 & 84 \\
\hline$m_{2}$ & 10 & 17 & 32 & 75 & 88 \\
\hline$m_{3}$ & 14 & 20 & 97 & 98 & 88 \\
\hline$m_{4}$ & 14 & 20 & 82 & 78 & 88 \\
\hline$m_{5}$ & 14 & 20 & 80 & 82 & 96 \\
\hline$\vdots$ & $\vdots$ & $\vdots$ & $\vdots$ & $\vdots$ & $\vdots$ \\
\hline$m_{261}$ & 14 & 20 & 86 & 92 & 84 \\
\hline$m_{\max }$ & 14 & 20 & 98 & 98 & 100 \\
\hline
\end{tabular}

Tabel 1. Ini menggambarkan matriks keputusan dengan elemen baris merupakan alternatif nama siswa dan elemen kolom merupakan atribut jenis penilaian siswa.

2. Normalisasi Matriks Keputusan

Jika atribut pertama ini adalah tipe menguntungkan, maka dapat dinormalisasi dengan menentukan nilai yang terbesar dari banyaknya alternatif yang bersesuaian dari atribut pertama, tampilannya seperti matriks di bawah ini:

$$
x_{i 1}=\left[\begin{array}{c}
14 \\
10 \\
14 \\
14 \\
14 \\
\vdots \\
14
\end{array}\right]
$$

Setelah matriks di atas terbentuk, kemudian ditentukan nilai terbesar dari atribut pertama dari seluruh alternatif yang bersesuaian.

$$
x_{i 1} \max =[14]
$$

Selanjutnya, dilakukan normalisasi matriks pada atribut pertama mengikuti banyaknya alternatif menggunakan persamaan (2.2)

$$
\begin{gathered}
N_{11}=\frac{x_{11}}{x_{i 1} \max }=\frac{14}{14}=1 \\
N_{21}=\frac{x_{21}}{x_{i 1} \max }=\frac{10}{14}=0,714285714 \\
N_{31}=\frac{x_{31}}{x_{i 1} \max }=\frac{14}{14}=1 \\
\vdots \\
N_{(261) 1}=\frac{x_{(261) 1}}{x_{i 1} \max }=\frac{20}{20}=1
\end{gathered}
$$

Perhitungan yang sama dilakukan masing-masing dengan banyaknya atribut mengikuti banyaknya alternatif yang bersesuaian. Dari perhitungan di atas diperoleh matriks normalisasi keputusan $N_{i j}$.

Tabel 2. Hasil Normalisasi Matriks Keputusan

\begin{tabular}{|c|c|c|c|c|c|}
\hline & $n_{1}$ & $n_{2}$ & $n_{3}$ & $n_{4}$ & $n_{5}$ \\
\hline$m_{1}$ & 1 & 1 & 0,819242 & 0,867347 & 0,84 \\
\hline$m_{2}$ & 0,714285 & 0,85 & 0,327988 & 0,765306 & 0,88 \\
\hline$m_{3}$ & 1 & 1 & 0,991254 & 1 & 0,88 \\
\hline$m_{4}$ & 1 & 1 & 0,835277 & 0,795918 & 0,88 \\
\hline$m_{5}$ & 1 & 1 & 0,816327 & 0,836735 & 0,96 \\
\hline
\end{tabular}




\begin{tabular}{|c|c|c|c|c|c|}
\hline$\vdots$ & $\vdots$ & $\vdots$ & $\vdots$ & $\vdots$ & $\vdots$ \\
\hline$m_{261}$ & 1 & 1 & 0,874636 & 0,938776 & 0,84 \\
\hline
\end{tabular}

Tabel 2. menggambarkan hasil normalisasi matriks yang diperoleh melalui perhitungan pada persamaan (2.2) yaitu menghitung normalisasi masing-masing atribut dengan alternatif yang bersesuaian.

3. Menghitung Nilai Rata-rata

Setelah mendapatkan nilai yang ternormalisasi, akan dihitung nilai rata-ratanya menggunakan persamaan (2.4) sepanjang kolom atau atribut, seperti berikut:

$$
\begin{aligned}
& N_{1}=\frac{1}{261} \sum_{i=1}^{m} N_{i 1}=0,948002 \\
& N_{2}=\frac{1}{261} \sum_{i=1}^{m} N_{i 2}=0,962452 \\
& N_{3}=\frac{1}{261} \sum_{i=1}^{m} N_{i 3}=0,793813 \\
& N_{4}=\frac{1}{261} \sum_{i=1}^{m} N_{i 4}=0,816112 \\
& N_{5}=\frac{1}{261} \sum_{i=1}^{m} N_{i 5}=0,790345
\end{aligned}
$$

Dari perhitungan di atas, dapat digambarkan melalui Tabel 3. dibawah bahwa hasil nilai rata-rata untuk setiap atribut, yaitu:

Tabel 3. Nilai Rata-rata

\begin{tabular}{|c|c|c|c|c|c|}
\hline & $n_{1}$ & $n_{2}$ & $n_{3}$ & $n_{4}$ & $n_{5}$ \\
\hline$m_{1}$ & 0,948002 & 0,962452 & 0,793813 & 0,816112 & 0,790345 \\
\hline
\end{tabular}

4. Perhitungan Variasi Preferensi

Menghitung nilai variasi preferensi untuk setiap atribut menggunakan persamaan (2.5) dengan melibatkan nilai normalisasi dan nilai rata-rata yang didapatkan pada perhitungan sebelumnya.

Dengan melakukan perhitungan, maka nilai variasi preferensi pada atribut pertama, yaitu:

$$
\begin{gathered}
\sigma_{11}=\left[N_{11}-N_{1}\right]^{2}=[1-0,948002]^{2}=0,002703772 \\
\sigma_{21}=\left[N_{21}-N_{1}\right]^{2}=[0,714285714-0,948002]^{2}=0,054623391 \\
\sigma_{31}=\left[N_{31}-N_{1}\right]^{2}=[1-0,948002]^{2}=0,002703772 \\
\vdots \\
\sigma_{(261) 1}=\left[N_{(261) 1}-N_{1}\right]^{2}=[1-0,948002]^{2}=0,002703772
\end{gathered}
$$

Secara keseluruhan perhitungan dilakukan sepanjang atribut dengan alternatif yang bersesuaian, digambarkan melalui Tabel 4 . di bawah hasil perhitungan pangkat dari normalisasi dikurangi rata-rata pada matriks $\boldsymbol{\sigma}_{\mathrm{ij}}$. 
Tabel 4. Hasil pangkat perhitungan normalisasi dikurangi rata-rata

\begin{tabular}{|c|c|c|c|c|c|}
\hline & $n_{1}$ & $n_{2}$ & $n_{3}$ & $n_{4}$ & $n_{5}$ \\
\hline$m_{1}$ & 0,002703772 & 0,00141 & 0,000647 & 0,002625 & 0,002466 \\
\hline$m_{2}$ & 0,054623391 & 0,012645 & 0,216992 & 0,002581 & 0,008038 \\
\hline$m_{3}$ & 0,002703772 & 0,00141 & 0,038983 & 0,033815 & 0,008038 \\
\hline$m_{4}$ & 0,002703772 & 0,00141 & 0,001719 & 0,000408 & 0,008038 \\
\hline$m_{5}$ & 0,002703772 & 0,00141 & 0,000507 & 0,000425 & 0,028783 \\
\hline$\vdots$ & $\vdots$ & $\vdots$ & $\vdots$ & $\vdots$ & $\vdots$ \\
\hline$m_{261}$ & 0,002703772 & 0,00141 & 0,006532 & 0,015046 & 0,002466 \\
\hline
\end{tabular}

Kemudian menjumlahkan hasil nilai pangkat dari normalisasi dikurangi rata-rata pada matriks $\sigma_{j}$

$$
\begin{aligned}
& \sigma_{1}=\sum_{i=1}^{m} \sigma_{i 1}=\sigma_{11}+\sigma_{21}+\sigma_{31}+\sigma_{41}+\sigma_{51}+\sigma_{\ldots 1}+\sigma_{(261) 1}=3,937172 \\
& \sigma_{2}=\sum_{i=1}^{m} \sigma_{i 2}=\sigma_{12}+\sigma_{22}+\sigma_{32}+\sigma_{42}+\sigma_{52}+\sigma_{\ldots 2}+\sigma_{(261) 2}=2,807031 \\
& \sigma_{3}=\sum_{i=1}^{m} \sigma_{i 3}=\sigma_{13}+\sigma_{23}+\sigma_{33}+\sigma_{43}+\sigma_{53}+\sigma_{\ldots 3}+\sigma_{(261) 3}=12,97551 \\
& \sigma_{4}=\sum_{i=1}^{m} \sigma_{i 4}=\sigma_{14}+\sigma_{24}+\sigma_{34}+\sigma_{44}+\sigma_{54}+\sigma_{\ldots 4}+\sigma_{(261) 4}=12,97914 \\
& \sigma_{5}=\sum_{i=1}^{m} \sigma_{i 5}=\sigma_{15}+\sigma_{25}+\sigma_{35}+\sigma_{45}+\sigma_{55}+\sigma_{\ldots 5}+\sigma_{(261) 5}=8,856469
\end{aligned}
$$

Diperoleh hasil matriks variasi preferensi $\boldsymbol{\sigma}_{\mathbf{j}}$

Tabel 5. Nilai Variasi Preferensi

\begin{tabular}{|c|c|c|c|c|c|}
\hline & $n_{1}$ & $n_{2}$ & $n_{3}$ & $n_{4}$ & $n_{5}$ \\
\hline$m_{1}$ & 3,93717257 & 2,807031 & 12,97551 & 12,97914 & 8,856469 \\
\hline
\end{tabular}

5. Perhitungan Nilai Penyimpanagan Preferensi

Nilai Variansi Preferensi yang didapat, kemudian dicari Penyimpangannya, yaitu:

$$
\begin{aligned}
& \varphi_{1}=1-3,937172=-2,93717 \\
& \varphi_{2}=1-2,807031=-1,80703 \\
& \varphi_{3}=1-12,97551=-11,9755 \\
& \varphi_{4}=1-12,97551=-11,9791 \\
& \varphi_{5}=1-8,856469=-7,85647
\end{aligned}
$$

Kemudian digambarkan pada Tabel 6. Dibawah ini:

Tabel 6. Nilai penyimpangan Preferensi

\begin{tabular}{|c|c|c|c|c|c|}
\hline & $n_{1}$ & $n_{2}$ & $n_{3}$ & $n_{4}$ & $n_{5}$ \\
\hline $\mathrm{m}_{1}$ & $-2,93717$ & $-1,80703$ & $-11,9755$ & $-11,9791$ & $-7,85647$ \\
\hline
\end{tabular}

Hasil perhitungan total nilai penyimpangan pada matriks $\varphi_{j}$, yaitu:

$\sum \varphi_{j}=-2,93717-1,80703-11,9755-11,9791-7,85647=-36,5553$

6. Perhitungan Nilai Bobot

Selanjutnya menghitung bobot atribut menggunakan persamaan (2.7) yang ditunjukkan pada perhitungan dibawah ini:

$$
\omega_{1}=\frac{-2,93717}{-36,5553}=0,080348
$$


Kemudian digambarkan pada Tabel 7. Dibawah ini:

$$
\begin{gathered}
\omega_{2}=\frac{-1,80703}{-36,5553}=0,049433 \\
\omega_{3}=\frac{-11,9755}{-36,5553}=0,3276 \\
\omega_{4}=\frac{-11,9791}{-36,5553}=0,327699 \\
\omega_{5}=\frac{-7,85647}{-36,5553}=0,21492
\end{gathered}
$$

Tabel 7. Nilai Bobot

\begin{tabular}{|c|c|c|c|c|c|}
\hline & $n_{1}$ & $n_{2}$ & $n_{3}$ & $n_{4}$ & $n_{5}$ \\
\hline$m_{1}$ & 0,080348 & 0,049433 & 0,3276 & 0,327699 & 0,21492 \\
\hline
\end{tabular}

7. Perhitungan PSI

Perhitungan PSI dilakukan dengan mengalikan normalisasi dan bobot pada setiap atribut bersesuaian dengan alternatifnya. Untuk hasil perkalian atribut pertama diperoleh sebagai berikut:

$\theta_{11}=N_{11} \omega_{1}=1 * 0,080348=0,080348$

$\theta_{21}=N_{21} \omega_{1}=0,714285 * 0,080348=0,057392$

$\theta_{31}=N_{31} \omega_{1}=1 * 0,080348=0,080348$

$\vdots$

$\theta_{(261) 1}=N_{(261) 1} \omega_{1}=1 * 0,080348=0,080348$

Perhitungan yang sama dilakukan masing-masing dengan banyaknya atribut mengikuti banyaknya alternatif yang bersesuaian, sehingga keseluruhan dapat digambarkan melalui Tabel 8, yaitu:

Tabel 8. Perhitungan perkalian normalisasi dengan bobot

\begin{tabular}{|c|c|c|c|c|c|}
\hline & $n_{1}$ & $n_{2}$ & $n_{3}$ & $n_{4}$ & $n_{5}$ \\
\hline$m_{1}$ & 0,080349 & 0,049433 & 0,268383 & 0,284229 & 0,180533 \\
\hline$m_{2}$ & 0,057392 & 0,042018 & 0,107449 & 0,25079 & 0,18913 \\
\hline$m_{3}$ & 0,080349 & 0,049433 & 0,324734 & 0,327699 & 0,18913 \\
\hline$m_{4}$ & 0,080349 & 0,049433 & 0,273636 & 0,260822 & 0,18913 \\
\hline$m_{5}$ & 0,080349 & 0,049433 & 0,267428 & 0,274197 & 0,206323 \\
\hline$\vdots$ & $\vdots$ & $\vdots$ & $\vdots$ & $\vdots$ & $\vdots$ \\
\hline$m_{261}$ & 0,080349 & 0,049433 & 0,28653 & 0,307636 & 0,180533 \\
\hline
\end{tabular}

Setelah mendapatkan hasil perkalian pada tabel di atas, kemudian dijumlahkan sepanjang atribut dengan masing-masing alternatif untuk memperoleh hasil PSI, sebagai berikut:

$$
\begin{gathered}
\sum_{j=1}^{n} \theta_{1 j}=\theta_{11}+\theta_{12}+\theta_{13}+\theta_{14}+\theta_{15}=0,862926 \\
\sum_{\substack{j=1 \\
n}}^{n} \theta_{2 j}=\theta_{21}+\theta_{22}+\theta_{23}+\theta_{24}+\theta_{25}=0,646778 \\
\sum_{j=1}^{n} \theta_{3 j}=\theta_{31}+\theta_{32}+\theta_{33}+\theta_{34}+\theta_{35}=0,971344 \\
\vdots \\
\sum_{j=1}^{n} \theta_{(261) j}=\theta_{(261) 1}+\theta_{(261) 2}+\theta_{(261) 3}+\theta_{(261) 4}+\theta_{(261) 5}=0,90448
\end{gathered}
$$

Diperoleh hasil preferensi (PSI) keseluruhan atau skor masing-masing alternatif dengan membentuk matriks berukuran $n \times 1$ yang digambarkan pada Tabel 9, dibawah ini: 
Tabel 9. Nilai PSI

\begin{tabular}{|c|c|}
\hline & $n_{1}$ \\
\hline$m_{1}$ & 0,862926 \\
\hline$m_{2}$ & 0,646778 \\
\hline$m_{3}$ & 0,971344 \\
\hline$m_{4}$ & 0,853369 \\
\hline$m_{5}$ & 0,87773 \\
\hline$\vdots$ & $\vdots$ \\
\hline$m_{261}$ & 0,90448 \\
\hline
\end{tabular}

8. Hasil akhir alternatif siswa berprestasi yang terpilih digolongkan menurut nilai yang tertinggi untuk memudahkan interpretasi dari implementasi yang diberikan.

Tabel 10. Solusi Alternatif

\begin{tabular}{|c|c|c|}
\hline Alternatif & Nama Siswa & Nilai \\
\hline $\boldsymbol{m}_{\mathbf{4 2}}$ & A & $\mathbf{0 , 9 8 9 4 9 2}$ \\
\hline $\boldsymbol{m}_{\mathbf{6 7}}$ & B & $\mathbf{0 , 9 7 7 5 5 4}$ \\
\hline $\boldsymbol{m}_{\mathbf{2 3 6}}$ & C & $\mathbf{0 , 9 7 6 5 9 8}$ \\
\hline $\boldsymbol{m}_{28}$ & D & $\mathbf{0 , 9 7 5 1 6 5}$ \\
\hline $\boldsymbol{m}_{38}$ & E & $\mathbf{0 , 9 7 2 2 9 9}$ \\
\hline
\end{tabular}

\section{Kesimpulan}

Berdasarkan pembahasan dalam penelitian ini, peneliti menyimpulkan beberapa hasil penelitian sebagai berikut, pengambilan keputusan pemilihan siswa berprestasi, akan membantu pihak sekolah dalam memilih siswa terbaik yang objektif untuk diikutsertakan pada kegiatan penalaran keagamaan, sehingga tidak mengambil keputusan yang subjektif dari siswa yang memiliki nilai rapor terbesar.

\section{Acknowledge}

Ucapan terima kasih diberikan kepada guru PAI SMPN X yang telah bersedia memberikan data dalam penelitian ini.

\section{Daftar Pustaka}

[1] R. Attri and S. Grover, "Application of Preference Selection Index Method for Decision Making Over The Design Stage of Production System Life Cycle,” J. King Saud Univ. - Eng. Sci., 27(2), 207-216, 2015.

[2] Siahaan, M. K., Mesran, M., Hutabarat, S. A., \& Afriany, J, "Sistem Pendukung Keputusan Penentuan Prioritas Pembangunan Daerah Menerapkan Metode Preference Selection Index (PSI)," KOMIK (Konferensi Nasional Teknologi Informasi dan Komputer), 2(1), 2018.

[3] Panggabean, R., \& Hasibuan, N. A,"Penerapan Preference Selection Index (PSI) Dalam Sistem Pendukung Keputusan Pengangkatan Supervisor Housekeeping," Resolusi: Rekayasa Teknik Informatika dan Informasi, 1(2), 85-93, 2020.

[4] Panggabean, R., \& Hasibuan, N. A, "Penerapan Preference Selection Index (PSI) Dalam Sistem Pendukung Keputusan Pengangkatan Supervisor Housekeeping," Resolusi: Rekayasa Teknik Informatika dan Informasi, 1(2), 85-93, 2020.

[5] P. K. Pendidikan, "Peranan Supervisi dalam Peningkatan Kualitas Pendidikan Oleh Maralih Abstrak,"1(1), 179-192, 2014.

[6] F. Syahputra, M. Mesran, I. Lubis, and A. P. Windarto, "Sistem Pendukung Keputusan 
Pemilihan Guru Berprestasi Kota Medan Menerapkan Metode Preferences Selection Index (Studi Kasus : Dinas Pendidikan Kota Medan)," KOMIK (Konferensi Nas. Teknol. Inf. dan Komputer), 2(1), 147-155, 2018.

[7] B. Vahdani, S. M. Mousavi, and S. Ebrahimnejad, "Soft Computing-Based Preference Selection Index Method for Human Resource Management," J. Intell. Fuzzy Syst., 26(1), 393-403, 2014.

[8] M. Mesran, N. Huda, S. N. Hutagalung, K. Khasanah, and A. Iskandar, "Sistem Pendukung Keputusan Pemilihan Supervisor Terbaik Pada Bagian Perencanaan PT. PLN (Persero) Area Medan Menerapkan Preference Selection Index," KOMIK (Konferensi Nas. Teknol. Inf. dan Komputer), 2(1), Oct. 2018.

[9] M. K. Siahaan, M. Mesran, S. A. Hutabarat, and J. Afriany, "Sistem Pendukung Keputusan Penentuan Prioritas Pembangunan Daerah Menerapkan Metode Preference Selection Index (PSI),” KOMIK (Konferensi Nas. Teknol. Inf. dan Komputer), 2(1), 370-375, 2018. 